Інна ШВАЙКА, orcid.org/0000-0001-9967-394X аспірантка кафедри історії України Харківського національного університету імені В. Н. Каразіна (Украӥна, Харків) innashvaika2111@gmail.com

\title{
ПОРІВНЯЛЬНИЙ АНАЛІЗ ВІДЗНАЧЕННЯ ОСНОВНИХ ХРИСТИЯНСЬКИХ СВЯТ НІМЕЦЬКИМИ КОЛОНІСТАМИ ТА УКРАЇНСЬКИМ НАСЕЛЕННЯМ (КІНЕЦЬ ХVIII - ПОЧАТОК ХХ ст.)
}

У статті досліджується питання взаємодї німецьких колоністів з українським населенням у культурному аспекті, а саме як і в який спосіб німецькі переселенці сприймали традиційні украӥнські свята. Було зроблено спробу виявити спільні та окремі риси у відзначенні основних релігійних свят. Німецькі колоністи були християнами-протестантами, украӥниі-християнами-православними. Тому в основному релігійні свята були спільними. Різними були календар святкування та обрядовість. Зроблено висновок про те, щзо вивчення изього питання є важливим завданням задля науковців для кращцого розуміння міжетнічних відносин, щуо склалися.

Ключові слова: німиі, колоністи, украӥнці, традиційні свята, християнство, протестантизм.

Jim. 9.

Inna SHVAIKA,

PhD Student of History of Ukraine, V. N. Karazin Kharkiv National University(Ukraine, Kharkiv) innashvaika2111@gmail.com

\section{COMPARATIVE ANALYSIS OF THE CELEBRATION OF MAJOR CHRISTIAN HOLIDAYS BY GERMAN COLONISTS AND UKRAINIAN POPULATION (LATE XVIII - EARLY XX CENTURY)}

This study covers the period from the XVIII century to the early XX century. The lower boundary corresponds to the time of the resettlement of German colonists in the territory of Ukraine. The upper boundary corresponds to the start of mass emigration of colonists to American countries. Territorial boundaries of the research cover the territory of modern Ukraine.

At the time of establishment of colonies in Ukraine by the Germans as well as Ukrainians had already formed a cultural array, so all the facts of the relations were initially due to economic feasibility. However, having moved, German colonists got trapped in the environment which was vital to adapt to and settle down in, which led to the expansion of relations with the surrounding population, not only in the aspect of economy but also culturally. It is necessary to pay attention to the fact that the relations in any aspect on the Ukrainian side were solely based on economic feasibility and benefit.

The purpose of this study is to highlight the facts of the relations of German colonists with the Ukrainian population during the celebration of major Christian holidays.

In connection with this purpose the following tasks have been assigned:

- to research how the German colonists and Ukrainian population celebrated the major Christian holidays;

- to identify similarities while celebrating Christian holidays;

- to identify the distinctive features during the celebration of religious holidays;

- to study out and research the facts of the relations and the main driving forces of these relations during the celebration of religious holidays by the Ukrainians and the colonists;

This study is based on the research and exploration of culture and household of the Ukrainians and German colonists that were made after Ukraine gained independence. The materials of the contemporary researchers of the colonists and the memoirs of the colonists themselves, which were published after the emigration of Germans abroad, have also been used in this study. 
This study deals with the issue of the interaction between the German colonists and Ukrainian population in the cultural aspect, namely how German immigrants perceived traditional Ukrainian holidays. An attempt has been made to identify similar and distinctive features in celebrating major religious holidays such as New Year, Maslyana/Pancake Week (among the colonists of Kimersy), Easter, Whit Sunday, Christmas. German colonists were Protestant Christians, Ukrainians were Orthodox Christians. Thus, overall, religious holidays were common. This contributed to the proper understanding and respect for traditions and celebration of Christian holidays. The calendars of the celebration and the rituals were different. It was concluded that the study of this issue is an important task for scientists in order to understand the inter-ethnic relations existing between the colonists and Ukrainians better, because having researched a number of sources, we can conclude that the colonists were not such a closed community, as it is stated by most of the contemporary scientists. German colonists actively engaged with Ukrainian not only in the aspect of economy but also communicated in the area of culture.

Key words: Germans, colonists, Ukrainians, traditional holidays, Christianity, Protestantism.

Ref. 9.

Инна ШВАЙКА, аспирантка кафедры истории Украины Харьковского национального университета имени В. Н. Каразина (Украина, Харьков) innashvaika2111@gmail.com

\section{СРАВНИТЕЛЬНЫЙ АНАЛИЗ ПРАЗДНОВАНИЯ ГЛАВНЫХ ХРИСТИАНСКИХ ПРАЗДНИКОВ НЕМЕЦКИМИ КОЛОНИСТАМИ И УКРАИНСКИМ НАСЕЛЕНИЕМ (КОНЕЦ ХVIII - НАЧАЛО ХХ веКа)}

В статье исследуется вопрос взаимодействия немеиких колонистов с украинским населения в культурном аспекте, а именно по каким образом немецкие переселенцы воспринимали традиционные украинские праздники. Была предпринята попытка выявить общие и отдельные черты в праздновании основных религиозных праздников. Исследование охватывает период кониа XVIII - начала XX в. Немеикие колонисты были христианами-протестантами, Украинцы христианами-православными, поэтому основные религиозные праздники были общими. Разным был календарь празднования и обряды. Сделан вывод о том, что изучение данного вопроса является важной задачей для ученых для лучшего понимания сложившихся межэтнических отномений.

Ключевые слова: немиы, колонисты, Украинцы, традищионные праздники, христианство, протестантизм.

Лит. 9.

Виклад основного матеріалу. Пропоноване дослідження охоплює період від кінця XVIII до початку XX ст. Нижня межа відповідає часу переселення німецьких колоністів на територію України, а верхня - початку масової еміграції колоністів до країн Америки. Територіально межі дослідження охоплюють територію сучасної України.

На час, коли німецькі колоністи переселялися на територію України, як у німців, так і в українців вже був сформований культурний масив. Але оскільки ці два етноси жили по сусідству, відбувалася їхня взаємодія у різних аспектах: економічному, соціальному, культурному. Але німецькі колоністи переселяючись, потрапили в середовище, у якому життєво необхідно було адаптуватися і прижитися, що спонукало до розширення зв'язків із навколишнім населенням не тільки в економічному аспекті, але і культурному. Слід приділити увагу тому, що з боку українського населення взаємовідносини у будь-якому аспекті грунтувалися на економічній доцільності та вигоді.

Аналіз останніх досліджень. Першим, хто звернувся до питання святкування німецькими колоністами свят, ще у XIX ст. був А. Клаус. Представник німецького етносу, він написав роботу «Наші колонії, досвід та матеріали по історії та статистиці іноземних колоній», у якій зобразив широку і різнобічну картину життя колоністів в історичній ретроспективі, дослідив широке коло архівних джерел. Варто також відзначити спогади, залишені П. К. Галлером «Спогади. Побут німецьких колоністів у 60-х роках XX століття». У роботі всебічно описано життя та побут німецьких колоністів. Особлива увага звернена на святкування релігійних свят 
та головних подій у їхньому житті. Велике значення для дослідження мають також «Десять спогадів про Григорівку» Т. Фреза. У цих спогадах викладена історія виникнення та розвитку села Григорівка. Домінують відомості про школу, церкву, національні та релігійні свята, а також про відносини з місцевим населенням.

Варто відзначити працю І. Кулинича і Н. Кривець, яка була видана після здобуття Україною незалежності. Робота, що характеризується фундаментальним, аналітичним стилем викладу матеріалу, стала першим виданням у вітчизняній історіографії, де було комплексно досліджено суспільно-політичне й соціально-економічне життя німецьких колоністів від часу їх переселення на територію України і до кінця 20-х рр. ХХ ст.

Досить грунтовне видання, яке стосується німецьких колоністів, опублікував В. Васильчук. У книзі автор всебічно висвітлює розвиток німецьких колоній на території України.

Метою пропонованої розвідки є виділення фактів взаємовідносин німецьких колоністів 3 українським населенням під час відзначення основних християнських свят.

У зв'язку з поставленою метою були сформульовані такі завдання:

- дослідити у який спосіб відзначалися основні християнські свят анімецькими колоністами та українським населенням;

- виявити спільні риси під час відзначення християнських свят;

- виявити відмінні риси під час відзначення релігійних свят;

- 'ясувати та дослідити факти взаємовідносин та головні рушійні сили до цих відносин під час відзначення релігійних свят колоністами та українцями;

Виклад основного матеріалу. Німецькі колоністи у своєму повсякденному житті в основному керувалися правилами Закону Божого. Ці правила стимулювали і контролювали певною мірою економічне, соціальне і духовне життя німецьких переселенців. Тому саме вивчення культурного взаємовпливу українців та німців є важливим завданням для кращого розуміння економічних і соціальних питань.

Особливу роль у житті німецьких переселенців відігравала релігія, у цьому випадку - протестантство. Цей напрям був сформований у Західній Європі у XVI ст. Віросповідні традиції німецькими колоністами були перенесені ними до православної Російської імперії, де знайшли досить сприятливу основу для існування. Розуміючи особливу роль релігійного чинника у житті держави, уряд не тільки підтримував православ'я, але і толерантно ставився до інших гілок християнства. При розробці плану переселення цьому аспекту надавалася особлива увага. Усім колоністам-протестантам гарантувалися належні умови організації релігійного життя, не насадження православ'я, толерантне ставлення до їхньої віри, але за умови не розповсюдження ними протестантизму серед корінного населення. Характерними рисами релігійного життя колоністів в Україні були як і поважливе ставлення до православ'я, так і певна замкнутість всередині своєї общини.

Першим святом, яке було традиційним в українській культурі, слід вважати Новий Рік. У колоністів Новий Рік сприймався як цивільне свято, тому його особливо майже не святкували. У поодиноких випадках святкувався лише один день. Але колоністи з повагою приймали дітей та молодь, які приходили із сусідніх українських поселень. Зазвичай це були діти під керівництвом старшого, вони несли з собою мішки з гостинцями. Заходячи до будинків колоністів, обсипали їх пшеницею, житом, ячменем, за що отримували від господарів солодощі або гроші $[2,23]$.

Українці вечір напередодні Нового року називали «Щедрий вечір». Цього вечора по хатах ходили щедрувальники (раніше це були винятково чоловіки), які співали пісні на добрий врожай наступного року. Зранку після «Щедрого вечора» ще до схід сонця чоловіки ходили від хати до хати та посівали зерном підлогу, це також було своєрідним побажанням гарного врожаю у наступному році $[9,19]$.

Масляна неділя у колоністів взагалі ніяк не святкувалася. Цей день вважався буденним, і всі члени общини виконували щоденну роботу незважаючи на те, що українські сусіди зазвичай святкували Масляну з неабияким розмахом - цілий тиждень $[3,44]$. В українців Масляна символізувала прощання із зимою і зустріч весни, а також початок Великого посту, який тривав до 
самого Великодня. Німецькі колоністи не дотримувалися не тільки Великого посту, а й взагалі не обмежували себе в їжі $[1,164]$.

Своєрідним прототипом Масляної у колоністів можна вважати свято Кірмерс, яке відбувалося восени, коли вже був зібраний увесь урожай і закінчені роботи із землею. Кімерси святкувалися у різних колоніях у різні неділі протягом декількох тижнів. Це свято порівнюють із Масляною, оскільки виражалося народним гулянням [4, 156].

Наступне велике свято - Великдень. Варто зазначити, що колоністи святкували Великдень раніше, ніж українці. Але для обох етносів це було надзвичайно важливе релігійне свято. У пасхальні дні як колоністи, так і українці залишали свою щоденну роботу і намагалися присвятити цей час справам духовним. У колоністів ще на початку тижня відчувався святковий настрій, четвер і п’ятниця були в особливій пошані, адже в ці дні все село мало причастись. День перед Великою п'ятницею називали Зеленим четвергом. Усі будинки вбиралися по-весняному. Діти несли вербу, квіти. У цей день пекли паски - великі з капелюхом, як у гриба. Їх випікали великими і маленькими - для кожної дитини в родині. У суботу починали фарбувати яйця та пекти печиво, калачі, готувати м’ясні страви. Варто зазначити, що, як і українці, німці фарбували яйця на Великдень за допомогою лушпиння із цибулі, отримуючи в кінцевому результаті коричневий колір, а також соку буряка, отримуючи червоний колір. Усю роботу намагалися закінчити до вечора, бо увечері в церквах відбувалася служба [3, 93], що для українців була дуже важливою. У колоністів служба у церкві звечора у суботу не була урочистою, і вони могли за бажанням іiі не відвідувати. Опівночі в українських Церквах починалася урочиста служба, яка тривала до ранку. Під час цієї служби святилися паски і яйця. У німецьких протестантських общинах служба починалася вже зранку і тривала до обіду. Але у протестантській релігії не визнавалося освячення їжі $[8,61]$. Варто зазначити, що під час приготування до Великодня колоністи зазвичай притрушували двори білим піском, для більш святкового вигляду. Можна навіть провести паралель із українськими традиціями на селі, де і сьогодні залишається традиція перед Великоднем притрушувати двір та клумби білим піском. Діти колоністів лягаючи спати, клали під ліжко свої шапки, для того, щоб у них зайчик вночі приніс великодні фарбовані яйця. Зранку діти у своїх шапках знаходили крашанки, печиво та цукерки $[2,115]$. Що стосується українського населення, то в українців не було такої великодньої традиції - їм подарунки приносив Святий Миколай.

Великдень святкувався три дні як колоністами, так і українцями. Найбільше свято було у неділю. У цей день заборонялося робити будь-яку роботу. Понеділок також вважався святом, але люди вже могли виконувати свої повсякденні справи. У вівторок після обіду всі поверталися до звичного життя, навіть йшли в поле, якщо дозволяла погода [7, 221].

Увесь час, протягом семи тижнів від Масляної неділі і до Великодня, українці дотримувалися суворого посту. Як вже зазначалося вище колоністи не практикували ніяких обмежень у їжі.

Святкування Трійці відрізнялося у колоністів та українців. Більшість німецьких сімей намагалося до свята прибрати двір, приготувати всю святкову їжу заздалегідь для того, щоб мати можливість без перешкод святкувати. Трійця для колоністів мала величезне значення ще й через те, що цього дня молоді люди хлопці та дівчата приймали конфірмацію, тобто хрещення і перше причастя. Це було найважливіше свято для кожного колоніста. Класна кімната, де навчалися діти, рясно прикрашалася квітами. Дівчата одягалися у білі довгі сорочки й чіпляли квітку. Діти до 12 років не могли бути охрещеними тому, що вони ще не могли служити громаді, а кожен правовірний меноніт чи лютеран повинен вступати в церкву лише усвідомлено задля того, щоб мати можливість служити громаді $[9,48]$. Напередодні цієї події всі збиралися в церкві і тут у присутності батьків проводився публічний іспит для майбутнього протестанта, за яким йде публічна сповідь. Після богослужіння - урочистого і тривалого - вони отримують причастя і одночасно в пам'ять про подію аркуш з малюнками з життя Христа і з відповідними текстами; рукою пастора приписується, що такий-то, народився тоді-то, у такий-то день і рік конфірмований ним, пастором, таким-то.

В українському суспільстві людина отримувала хрещення і приєднувалася до православної церкви майже відразу після народження за рішенням батьків через хрещених батьків, які 3 
моменту хрещення дитини несли відповідальність за їі духовне виховання. У колоністів не було хрещених батьків через те, що людина сама усвідомлено приходила до конфірмації.

У колоністів Трійцю святкували два дні. Вранці першого дня всі йшли на службу до церкви, потім починалося святкування, яке тривало весь день, а інколи і ніч. Свято Трійці було також приводом для оголошення заручин серед молоді. Хлопці заздалегідь домовлялися з обраницею і вночі ставили біля воріт нареченої високу жердину з прив'язаним вгорі кущем зелені, на наступну ніч жердина зникала. 3 цього моменту дівчина вважалася зарученою $[1,88]$.

В українців свято Трійці мало також свої особливості. Напередодні свята оселю та весь двір прикрашали гілками дерев, квітами. Люди вірили, що так можна відігнати злі сили від оселі та двору. У церкві служба відбувалася один день. Наступний день також вважався святом, але люди могли виконувати свою повсякденну роботу [7, 325].

Наступним великим святом варто вважати Різдво. У колоністів Різдво припадало на 25 грудня і тривало три дні. Зазвичай перший день святкували із родиною, другий - із родичами з боку чоловіка, а третій - з друзями. Традиційна їжа була практичною і готувалася заздалегідь, що потім під час святкування не поратися на кухні. Особливо з нетерпінням Різдва чекали діти, вони, як і діти в усьому християнському світі, зазвичай отримували подарунки. У цей день їм дарували солодощі, приладдя для школи або іграшки $[9,82]$.

В українців Різдво святкувалося 7 січня. Напередодні ввечері ходили колядники із Віфлеємською зіркою, сповіщаючи всіх, що Христос народився. Служба в церкві починалася опівночі і тривала до ранку, після чого люди приходили додому і святкували в родинному колі. На столах уже можна було побачити страви тваринного походження, заборонені під час Різдвяного посту, який тривав із кінця листопада. Зазвичай в українських родинах дітям дарували подарунки у вигляді солодощів та іграшок [5, 75].

Висновки. Отже, календар свят у німецьких колоністів та українців був схожим. Як і німці, українці були християнами. Але оскільки українці православні, а колоністи були протестантами, то і традиції відрізнялися. На сьогодні ця тема лише частково досліджується істориками. Подальше вивчення питання було б доцільним для кращого розуміння процесів, які визначали взаємодію культур. Взаємовідносини між німецькими колоністами і українським населення мали серйозний вплив на економічний та соціальний розвиток етносів. Релігійний аспект відігравав у цьому одну з найголовніших ролей, тому означене питання потребує більш глибокого вивчення.

\section{СПИСОК ВИКОРИСТАНИХ ДЖЕРЕЛ І ЛІТЕРАТУРИ}

1. Васильчук В. М. Німці в Україні. Історія і сучасність / В. М. Васильчук. - К.: Вид. центр КНПУ, 2004. $-340 \mathrm{c}$.

2. Галлер П. Воспоминания. Быт немцев-колонистов у 60-х годах XIX века / П. Галлер // Вожское областное научное общество краеведенья. - Саратов, 1927. - 145 с.

3. Клаус А. Наши колонии: опыт и материалы по истории и статистике иностранных колоний Росии / А. Клаус. - СПб.: Тип В. Нусвальта, 1869. - 455 с.

4. Кулинич І. М. Нариси з історії німецьких колоній в Україні / І. М. Кулинич, Н. В. Кривець - К.: Ін-т історії України НАН України, 1995. - 345 с.

5. Пригорницький В. В. Народні свята / В. В. Пригорницький. - К.: «Освіта», 1993. - 146 с.

6. Сергійчук В. Німці в Україні / В. Сергійчук // Український світ. - 1993. - Ч. 1-2. - С. 28-29.

7. Українське народознавство: Навч. посібник / За ред. С. П. Павлюка, Г. Й. Горинь, Р. Ф. Кирчива. Львів: Фенікс, 1994. - 608 с.

8. Хрящевська Л. М. Культурні традиції німецького населення Південної України у XIX початку XX ст. / Л. М. Хрящевська // Науковий вісник Одеського економічного університету. - 2009. № 7 (85). - C. $60-72$.

9. Friesen T. Memories of Grigorievka / T. Friesen, E. Dyck (Peters), G. Bergen. - CMBC Publications. Winnipeg, Manitoba, 1998. - $100 \mathrm{c}$.

\section{REFERENCES}

1. Vasylchuk V. M. Nimtsi v Ukraini. Istoriia i suchasnist / V. M. Vasylchuk. - K.: Vyd. tsentr KNPU, 2004. $-340 \mathrm{~s}$. 
2. Haller P. Vospomynanyia. Byt nemtsev-kolonystov u 60-kh hodakh XIX veka / P. Haller // Vozhskoe oblastnoe nauchnoe obshchestvo kraevedenia. - Saratov, 1927. - $145 \mathrm{~s}$.

3. Klaus A. Nashi kolonii: opyt i materialy po istorii i statistike inostrannykh koloniy Rosii / A. Klaus. $\mathrm{SPb}$.: Tip V. Nusvalta. 1869. $-455 \mathrm{~s}$.

4. Kulynych I. M. Narysy z istorii nimetskykh kolonii v Ukraini / I. M. Kulynych, N. V. Kryvets - K.: In-t istorii Ukrainy NAN Ukrainy, 1995. - $345 \mathrm{~s}$.

5. Pryhornytskyi V. V. Narodni sviata / V. V. Pryhornytskyi. - K.: «Osvita», 1993. - 146 s.

6. Serhiichuk V. Nimtsi v Ukraini / V. Serhiichuk // Ukrainskyi svit. - 1993. - Cz. 1-2. - S. 28-29.

7. Ukrainske narodoznavstvo: Navch. posibnyk / Za red. S. P. Pavliuka, H. Y. Horyn, R. F. Kyrchyva. Lviv: Feniks, 1994. -608 s.

8. Khriashchevska L. M. Kulturni tradytsii nimetskoho naselennia Pivdennoi Ukrainy u XIX - pochatku XX st. / L. M. Khriashchevska // Naukovyi visnyk Odeskoho ekonomichnoho universytetu. - 2009. - № 7 (85). S. $60-72$.

9. Friesen T. Memories of Grigorievka / T. Friesen, E. Dyck (Peters), G. Bergen. - CMBC Publications. Winnipeg, Manitoba, 1998. - 100 s.

Стаття надійшла до редакиії 6.03.2017 p. 